\title{
Balancing the Objectives of Corporate Governance: Social Welfare V Profitability
}

\author{
Adebola Adeyemi, $\mathrm{PhD}$ \\ Tutor, Centre for Law and Business, Lagos, Nigeria; \\ Partner, PAC Solicitors, Lagos, Nigeria
}

\begin{abstract}
Balancing social welfare issues with profitability is difficult and critical for the long-term success of a business entity. It is also difficult for managers to prioritise between the numerous competing interest of shareholders and different stakeholders. The paper examines the sphere within which businesses operates, introduces some terms common to social welfare and profitability, and investigates if any correlation exists between social issues and business profitability. The paper suggests that firms that exclude social welfare issues are doing so at their own risk.
\end{abstract}

Keywords: company, corporate governance, director, profitability, shareholders, social welfare, stakeholders DOI: $10.7176 / \mathrm{JLPG} / 83-06$

Publication date:March $31^{\text {st }} 2019$

\section{INTRODUCTION}

Whether decision-making in Corporations should be based solely on considerations of profit, in a narrow view, or should take into account the needs and interest of various constituents, or social welfare, more generally, has been a subject of conflicting debate since the seminal work of Jensen and Meckling (1976). The paper considers the assertion that owners, i.e., shareholders, should have priority in determining how business entities pursue their most important goal, i.e. profit maximization. Or put in another way, whether pursuing stakeholder interests negatively impacts on a company's financial performance? Those who believe the responsibility of a business is not limited to its shareholders alone have watered down this assumption. The proponents of this paradigm, which shall be considered in Section 2, urge that a business entity can make a profit while taking into account a whole range of other interests. A plethora of studies, critically considered in Section 3, has been carried out in this area using varying criteria and variables to test the relationship between social performance and financial performance. Others have tried to jettison the above and instead try to show that a business enterprise can pursue socially responsible goals and still remain profitable.

Here, social welfare issues would be taken to mean issues that affect a wide range of persons; such as employees, community relations, product safety, environmental considerations, etc., this inevitably dovetails into considering a wide range of stakeholder goals vis-à-vis their impact, if any, on shareholder value. Due to the internationalization of economic activity, the paper considers the impact of different corporate models, i.e. 'insider' (Rheine Capitalism) versus 'outsider' (Anglo-Saxon Shareholder model) in Section 4.

The growing body of literature in this respect is part of a long tradition of debate on balancing the interest of various groups related to a business entity. The coincidence of these pressures upsets the smooth running of a business where management fails to react or reacts half-heartedly to the yearnings of stakeholders. To this end, the paper considers the dilemma of managers in Section 5. Managers are in the unenviable position of trying to balance the conflicting interests. This is paramount for any manager that hopes to run a profitable and sustainable business enterprise.

Drawing on the above, the paper concludes in Section 6, by putting forward the view that, welfare issues may not be alien to the desire to make maximum returns. In other words, they could be viewed not as conflicting paradigms but as valuable supplements towards meeting the diverse interests of the different organs with interests/affected by the activities of a business entity.

\section{THE OBJECTIVES OF CORPORATE GOVERNANCE}

Before proceeding into the substance of the paper, it would be necessary to analyse the basis of this intellectual discourse by considering the development of the term 'Corporate Governance', and how it seeks to shape the way we understand the workings of the modern Corporation. The term corporate governance cuts across a number of disciplines, from management and finance to law and politics. There are substantial differences in definition depending on the model considered but a dominant trait runs through despite the lack of a universally accepted definition.

Corporate governance mechanisms are a means for reducing agency costs that arise as a result of the separation between ownership and control (Berle and Means, 1932). Berle and Means (1932) asserted that corporate shares were owned by a number of persons who were numerous and dispersed and consequently could not exercise control over the corporation they owned. However, in recent years the empirical validity of this 
image of the firm has been questioned (Demsetz and Lehn, 1985; Shleifer and Vishny, 1986). At present, corporate governance mechanisms are now seen as an invaluable tool for minimising destruction of firm value caused by conflicts of interest between the firm's stakeholders (Tirole, 2001; 4). According to Shleifer and Vishny (1997), corporate governance deals with the ways in which suppliers of finance to corporations assure themselves of getting a return on their investment. The importance of the term is brought home, as corporations would find it difficult if not impossible to attract outside capital where the contributors of finance are not confident that certain safeguards are in place to protect their investments.

Interestingly, firms operate in an environment where certain factors are in a state of flux, i.e. consumer tastes, market conditions, technological innovation, government policies, etc., in order to meet the goal of the firm, managers would need to prioritise and continually balance all of these to ensure that the firm meets its objectives. The objectives of management as to what constitutes effective corporate governance differs across jurisdictions owing to corporate culture and practice, legal origins, political ideology etc. This suggests that a country's economic ideology is important in determining its corporate governance practice (Roe, 2002; 601). Put in another way, the influence of corporate models and policy on corporate executives cannot be over-emphasised with the Anglo-American system promoting shareholder profit maximization while countries in continental Europe promote stakeholder wealth maximization.

Having considered the objectives of corporate governance, the next section considers the concept of social welfare and profitability.

\subsection{SOCIAL WELFARE AND PROFITABILITY- $A$ FASCINATING PARADOX.}

Some theorists posit that wealth maximization is the economic measure of social welfare (Kaplow and Shavel, 2001; 995). This assertion is difficult to reconcile in view of the fact that wealth maximization as a concept is nebulous and the term is not defined in terms of individual well being, which as we know, is one of the strong pillars of social welfare. The economic notion of social welfare is concerned with the distribution of income(Kaplow and Shavel, 2001; 968). To Kaplow and Shavel (2001), the concept of social welfare is primarily based on individual wellbeing. To them, individual wellbeing interacts with social welfare in a symmetric manner to the extent that redistributing income from the rich to the poor will tend to raise social welfare where marginal utility of income is greater for the poor than the rich. While to the utilitarian, the well being of the worse off individuals might be given greater prominence. The work of Rawls $(1971,75-83)$ in this regard is instructive. To Rawls, social welfare corresponds to the utility of the worse off individual. He however gives prominence to what he calls 'primary goods' instead of wellbeing (Rawls, 1971).

From the above, the belief that wealth maximization is the economic measure of social welfare, although incomplete, may be a good starting point in understanding issues of social welfare. There lies the paradox.

Social welfare as a concept is not, strictly speaking interchangeable with the term 'Stakeholder'. But in the context of this paper the term, social welfare, would be viewed from the perspective of stakeholder empowerment to enable an exploration of its effects on directing company policy. In other words, the stakeholder theory would be espoused with social welfare playing a very significant role. It would be out of place to state that corporations can be made responsible for all social welfare issues. What this paper attempts to espouse is that corporations should take into account social welfare issues to the extent that such issues affect their stakeholders as this may be positively correlated to the bottom line. The argument against a social welfare objective for corporations simply peters out when juxtaposed against the considerable degree of influence wielded by today's corporations.

\subsection{THEORETICAL FRAMEWORK}

Major theoretical contributions as it concerns the concept of profitability, which espouses shareholder wealth maximization, and social welfare, which represents accountability to a broad range of constituents, would be critically analysed and an attempt would be made to relate the issues to this paper as far as practicable. Both concepts are explored with a view to highlighting the way that firms have managed to interact with other constituents while pursuing their profit maximization objective.

The effort to seek external finance and the ingenious concept of limited liability has been described as the two most important factors responsible for the growth of the modern corporation. The above factors had a huge impact on the way corporations were to be run as the system was organized in such a way that ownership was separated from control (Berle and Means, 1932). There exists different approaches to analysing corporate governance issues, but this paper considers 'the agency theory' and 'the stakeholder theory' of the firm as they serve as appropriate lenses in viewing the twin issues of social welfare and profitability.

2.2.1 AGENCY THEORY

Agency relationships occur when Shareholders (Principals) engage Managers (Agents) to perform a service on their behalf, which often involves the delegation of some decision-making authority to the agent (Jensen and Meckling W., 1976). The assumption is that both parties have divergent interests which can be limited if the 
Principal establishes incentives or can appropriately monitor the Agent. Agency conflicts arise where the agent runs the firm in a way that is in conflict with the interests of the principal. Agents are assumed to be selfinterested and egoistic, leading them to pursue their own self-interest (Boatright, 1999). This inevitably results in agents focusing on short-termism rather than the maximization of long-term shareholder wealth maximization (SWM). This seems to be the case as individuals are assumed to behave 'rationally' by choosing courses of action that maximises their utility (Ogus, $1994 ; 24)$.

According to the finance paradigm, the primary objective for companies is shareholder wealth maximization. The term SWM could be defined by reference to management practices that enhance productivitycorporate unbundling and concentration on core competencies, the return of free cash flow to shareholders, compensation schemes that align incentives, and prompt restructuring of dysfunctional operations (Bratton, 2001; 1283). Further, Friedman, at his rhetorical best, argued that this is the 'one and only social responsibility of business' so long as businesses 'engage in open and free competition without deception or fraud' (Friedman, $1962 ; 133)$. This view of the corporation is used to support the assumption that corporations should serve the sole interest of shareholders (Leavitt, 1958; 49). Other writers have also reiterated this position as their view of the theory of the firm (Marcoux, 2003; Sternberg, 2000; 46).

\subsubsection{STAKEHOLDER THEORY}

The stakeholder concept has developed substantially despite its new and fairly humble background. Though R.E. Freeman did not invent the term, it was thrown onto centre-stage with the publication of his book in 1984, where he defined a stakeholder as 'any group or individual who can affect or is affected by the achievement of the organisation's objectives' (Freeman, 1984; 46). His accounts of the roots of the theory gave credence to Stanford Research Institute (SRI) International for its definition of the term. In its internal memo, the SRI defined stakeholders as 'those groups without whose support the organisation would cease to exist' (Ansoff, 1965; 34). Depending on the definition of a stakeholder that is used it could 'have substantial consequences on ethical, strategic, and policy conclusions' (Freidman and Miles, 2006; 4). The stakeholder concept is multifarious and replete with different philosophical underpinnings representing distinct views of various authors. The concept has been taken apart, moulded and remoulded by different theorist over the years to explain almost any specie of corporate behaviour. More importantly, the theory has been used to explain how firms ought to balance their economic function against their social function (Blair, 1998).

\subsection{ARE THE THEORIES ANTITHETICAL?}

In determining whether the theories are antithetical, the important question is can management pursue shareholder wealth maximization while taking into account stakeholder needs? In other words, can a company add value by managing risk, building a sustainable business and at the same time maximize shareholder wealth?

The difficulty in answering this question can be seen from the earlier exposition in this paper highlighting the dilemma often faced by managers in this regard. Managers occupy the unenviable position of formulating company policy, which to a large extent determines the company's interaction with the inputs of capital, factors of production and other constituents.

The academic literature is replete with a lot of arguments, some scholars have tirelessly urged against any sought of linkage between the stakeholder view of the firm and the agency paradigm (Friedman, 1962; Sternberg, 2000). According to Jensen $(1991 ; 238)$, the only moral obligation that managers have to deal with is to maximize returns to their shareholders as this results in effective allocation of resources. On the other hand, studies by other writers support the view that businesses that integrates stakeholder interests in their decisionmaking tend to be profitable on the long run (Freidman and Miles, 2006). Using the KLD index to measure the social performance of firms, some empirical evidence that stakeholder management leads to firm profitability can be found in the writings of Cochran and Wood (1984).

Taking the theories on face value, there appears to be a lot of inconsistencies between the objectives underpinning their philosophical orientation. For example, Donaldson and Preston (1995:71) speaking from a normative viewpoint urged that stakeholders are groups with legitimate interests in procedural and/or substantive aspects of corporate activities and must therefore be considered for its own sake and not merely because of its ability to further the interests of some other group, i.e. shareholders. However, on the other hand, scholars have urged that the theories might not be as divergent as originally thought. In fact, it has been argued, that it is possible to treat both theories within a single theoretical framework (Solomon, 2007; 27). In this regard Hill and Jones (1992) urge that a 'stakeholder-agency theory' could be developed by applying concepts and language specific to agency theory to the stakeholder theory.

Also important in evaluating similarities between both concepts is the role of managers in balancing the interests of shareholders and stakeholders. The role of managers would be considered in greater detail in later parts of the paper but here it is important to highlight the extent to which manager decision-making powers largely affects the way the company interacts with other stakeholders. For instance, managers are responsible for developing and setting strategy, identifying needs, and interests which may affect the smooth running of the 
firm's operations. As they are agents of the shareholders and since the managers also have a stake in the success of the firm, they occupy a position which makes it easier for them to balance responsibility and accountability with stakeholder wants and needs. Arguably, where a company is doing badly and managers decide to downsize or shut down a particular arm of its operations, employees, suppliers, local community, etc., feel the pinch. Shareholders are not spared as well, as the value of their investment drops. This goes to show that the interest of shareholders and stakeholders do converge to a certain extent.

In attempting to construct a hybrid model, the discussion dovetails into the next section, where the paper considers the issues affecting the measurement of social and financial performance.

\section{CORPORATE SOCIAL AND FINANCIAL PERFORMANCE}

The studies addressing the issue of the relationship between financial performance and welfare goals are varied. Some indicate a positive influence; others indicate a negative influence, while others are neutral.

\subsection{THEORETICAL ANALYSIS}

Reflecting on the lack of an appropriate level of analysis in the field of corporate social performance, it has been observed that the concept's theoretical framework and impact have not moved significantly beyond Wartick and Cochran's (1985) articulation (Wood, 1991; 693). There is no accepted method of testing and correlating the concept of social and financial performance, different researchers have employed different techniques and arrived at various results. What is regarded as a variable in one study might be regarded as a constant in another leading to spurious positive correlations between social responsibility and financial performance (Cochran and Wood, 1984; 55).

This has been blamed on the confusion about the meaning and relationship of corporate social performance compared with profitability. Taking full advantage of this situation was Friedman $(1970 ; 33)$ who stated that;

"The discussions of the "social responsibilities of business" are notable for their analytical looseness and lack of rigor... The first step towards clarity in examining the doctrine of the social responsibility of business is to ask precisely what it implies for whom."

From the above, it can be deduced that Friedman separated business from social responsibility by placing the issues into separate compartments. Friedman (1970) went on to decry the concept of corporate social responsibility stating that its proponents were preaching 'pure and adulterated socialism'. Notwithstanding, if scholars want the stakeholder theory to fulfil its aim as a theory of the firm, normative discourse must continue. The next section considers different approaches used in measuring social and financial performance.

\subsection{MEASURING FINANCIAL PERFORMANCE}

Is profitability measured by perusing the company's balance sheet? The balance relates to past information concerning the firm's performance during the immediate past financial year. In this regard it tells us little or nothing asides how the company performed in the last financial year. In measuring performance, we need performance measuring indexes that would enable us use the present to look into the future and project a company's prospects in the new financial year.

A range of approaches has been used to measure financial performance. However, most measures are broadly divided into investor returns and accounting returns. As the name implies, investor returns relates to returns to shareholders. Under this approach, a change in share price is used as the investor returns index (Moskowitz, 1972; Vance, 1975). Studies have shown that this measure is inadequate as change in share price is only one element of investor returns. Another important variable, which must be included in any measure of investor return, is dividend income. However, it has also been shown that this is insufficient as it leaves out another important factor, risk (Moskowitz, 1972; Vance, 1975). Even where the above has been adhered to, a researcher has to consider the efficient market hypothesis. In its simplest form, the theory states that as information concerning the cash flow of the firm becomes available, it would be factored into the firms share price (Fama, 1970). In other words, if social responsibility leads to improved financial performance, the market will immediately reflect this by altering the share price accordingly as it is assumed that the markets will reflect the available information. So as perception of a firm changes, any study carried out during such period must also reflect such change. Failure to do so, would lead to inefficiency.

The other primary method for measuring financial performance is accounting returns. This approach aims to relate firm earnings to different managerial policies. The common ones used are earnings per share (EPS) and price/earning ratio $(\mathrm{P} / \mathrm{E})$. However, this methods might not produce a true reflection of value, as factors like risk, accounting practices and financial leverage, which may influence test results, vary according to firms.

A lot has been said on the use of financial measures to assess performance. The standard formulation of the proper objective of management in the economics literature is that managers should seek to maximize the value of the residual after all fixed claims have been met (Parkinson, 1993; 90). It is important to state here that, maximizing the present value of the firm does not necessarily translate to maximizing shareholder wealth; this 
depends on the efficiency and ability of the stock market to effectively incorporate information concerning a particular stock into its market price. This is because historically, it has been shown that stock markets are not efficient all of the time.

\subsection{MEASURING SOCIAL PERFORMANCE.}

A study of more than seventy field studies on corporate social performance between 1983 and 1993 concluded that social performance could not be analysed using social issues, social responsibility or strategies of corporate responsiveness (Clarkson, 1995, 97). The data collected showed that managers carried out their duties without considering social issues and performance nor social responsibilities and responsiveness. On their part, Bowman and Haire (1975) used content analysis to measure firm activity based on representations made in the annual report. While the investment firm, Kinder Lydenberg Domini and Company has developed a pretty balanced and quite acceptable social index for measuring corporate social performance, known as the KLD social index. The index rates firms' social performance on eight levels including employee relations, products, community relations, and environmental stewardship (Agle et al., 1999, 515). Other indexes include FTSE4Good, and Dow Jones Sustainability index. They have provided researchers with some indications on the effects of company policy on social responsibility and financial performance.

The question is whether there is a positive relationship between corporate social performance and corporate financial performance?

A negative relationship between corporate social responsibility and performance has been explained on the basis of competitive disadvantage (Freidman and Miles, 2006, 238). In other words, socially responsible firms due to the extra costs incurred while pursuing socially responsible policies find themselves at a competitive disadvantage. The cost of intervention in social issues would inevitably be passed to consumers, as firms are reluctant to internalize such costs (Cartwright, 1990). According to Graves and Waddock (1994) corporate social performance is notoriously difficult to quantify. Their study suggests that improving a firm's social performance does not discourage institutional investors from buying shares (Waddock and Graves, 1997). This could be as a result of a lack of agreement on terms and normative bases, the multidimensionality of the construct and a variety of issues cutting across industry.

Waddock and Graves, (1997) studying profitability measures, found a significant relationship between return on equity (ROE) and corporate social performance (CSP) taking into consideration factors like employee relations, product innovation/safety, environmental stewardship, and community relations. They further stated that, a 'virtuous circle' exists between corporate social performance and financial performance (Waddock and Graves, 1997, 317).

From studies considered above, it would be safe to infer that there is no consensus on the outcomes of any one of the studies. Researchers need to do more work in this respect. Understandably, the conflicting results may be due to the different methodology employed by the various studies. The results of these studies may not be wrong and most importantly, they have considerably enhanced our understanding of the issues in question. The studies also show that firms are starting to recognize the weight of their economic and social impact and they are attempting to draw up strategies to adapt their processes to meet this challenge. The increased acceptance of the social and performance measurement indexes including FTSE4Good, Dow Jones Sustainability index are instructive in this regard.

\subsection{THE BUSINESS CASE FOR CORPORATE RESPONSIBILITY.}

Under this section the paper considers the possibility of using ethics, as a management tool, in maximizing the wealth of shareholders. Employing ethics in business is seen in some quarters as good business (Quinn and Jones, 1995). However, it is difficult to see how this approach would attract support unless it guarantees that shareholder wealth would not be diminished. According to the Task Force on Corporate Social Performance, businesses exist to meet the needs of society (Task Force on Corporate Social Performance Business and Society, 1980). Achieving this objective is their foremost responsibility; if they fail in this, they cannot reasonably be expected to assume other responsibilities. Further, employees would not want their pension contributions invested in a company which would not be able to outperform the market or at least record a return that is higher than the rate of inflation, so their investment remains valuable after they decide to terminate the scheme.

The role of the market in acting as a check on unethical behaviour is important. The creation of indices such as Dow Jones Sustainability Index, FTSE4Good Index, KLD Domini Social Indices indicates that investors are concerned with wider stakeholder issues. As firms who are seen to be doing nothing in improving the lot of their stakeholders immediately see the value of their shares plummet. That is assuming we have an efficient market, where information is readily reflected in the price of securities. A weak securities market where information asymmetry is prevalent would not be able to do this, as prices of shares would not adequately reflect the precise value of those shares. As Boatright (1999) sought to rely on the theory of Adam Smith's 'invisible hand' to explain that in a free market unethical behaviour would be punished whereby unethical firms would not be able 
to attract and exploit capital for the advancement of business operations.

From the above exposition, the paper infers that companies can maximize profits by taking into account the interest of their employees, consumers, and local community, and then to consider the impacts of the entity's activities on the environment. There has been a lot of progress made in this regard with companies publishing sustainability reports asides the traditional financial annual reports. For instance, as part of its 'business principles Shell emphasises on social performance and engagement with local communities (Shell Petroleum Development Company, 2017). The company has been in the forefront of publishing what can be termed social performance reports. Shell Petroleum Nigeria went on to inform investors in its 2017 annual report/form 20-F on ways in which it was managing environmental and social risks. It also stated it was co-operating with groups which provide investors and the general public with information and analysis about the environmental and social performance of companies. Concerning its staff, it publishes a separate Sustainability Review with a view to increasing internal information flow between management and employees. Shell hopes to create value for its shareholders by reducing its operational and financial risk. It recognises as significant risks, approval delays and disruption to existing operations by concerned communities. According to the Shell M.D, Country Chair Nigeria, fifty-four of Shell staff and contractors were kidnapped in 2005 by restive youths in the volatile Niger Delta area in Nigeria. Nine were killed in assaults or kidnappings (Shell Petroleum Development Company, 2006, 32). This situation has since improved with the oil Companies increasingly engaging with local communities and other stakeholders as a risk reduction mechanism. Further, Shell recognises as obvious benefits the positive perception of stakeholders with respect to the company's operations. Business entities in certain sectors of the economy need to deal with damage to their reputation where they are accused of neglecting or treating their stakeholders with contempt.

The above discussion, demonstrates that business entities are increasingly recognising that stakeholders can impact on their operations if the relationship with certain stakeholder groups are not managed. Business entities hope to be profitable and remain so, by engaging their stakeholders and meeting their expectations. Those who refuse to recognise and accommodate the views of stakeholder groups might record profits in the short term, but it remains to be seen how long abandoning stakeholder needs and wants can be sustained.

\subsection{THE EXTENT OF FIDUCIARY DUTIES IN RELATION TO PROPERTY RIGHTS COMPARING CORPORATE LAW IN NIGERIA AND THE UK}

Fiduciary duty can be described as a duty of utmost good faith, candour and confidence owed by a fiduciary to the beneficiary (Black's Law Dictionary, 2004, 1539). The duties include honesty, due care and skill, transparency, etc. It has been argued in the literature, that the obligations of agents (company management) to principals (shareholders) are of a different nature and cannot be equated with those between agents (company management) and third parties (stakeholders). To Berle and Means $(1932,336)$ whenever one man or group of men entrusted another... with the management of property, the second group became fiduciaries. As such they were obliged to act conscionably, which meant in fidelity to the interests of the persons whose wealth they had undertaken to handle. In other words, management stands in a fiduciary relationship to shareholders and no other group.

Scholars have offered counter arguments by suggesting that fiduciary duties of managers is more extensive and goes beyond their duties to shareholders (Dodd, 1932, 1158). Although Goodpaster (1991), with his concept of multi fiduciary stakeholder synthesis is of the view that shareholders are the only group to which managers owe fiduciary duties. He however recognised the existence of non-fiduciary obligations that may be owed to third parties (Goodpaster, 1991, 57). The extension of fiduciary duties to non-stockholders, in Goodpaster's (1991) view, would make stakeholders quasi-stockholders thereby interfering with one of the main pillars of corporate law. He argues against a transformation of stakeholder obligations into fiduciary obligations by a call to protect the sacred principal-agent relationship.

Evaluating the interest of shareholders as it relates to their property rights could be interpreted in different ways based on the concept of private property. The economic view of the firm demands that the corporation be run for the benefit of shareholders, since their property rights, i.e share ownership, is superior to all other interests that any other group may have in the corporation. To impose a trustee role on managers may amount to pushing the fiduciary concept too far (Monks and Minow, 2004, 53). Since shareholders are providers of finance, it is assumed that firms be run for their benefit, and where managers pursue social goals unauthorized by shareholders they are seen as having breached their agreement (Hasnas, 1998). Williamson (1985) argues that the shareholders' investment is at risk and needs to be adequately protected more than other perceived or actual investments in the firm. Only a survival of the firm can guarantee a possibility of a return on their investment (Williamson, 1985, 304 - 305). Their claims on company assets are not preferential and most importantly their relationship does not come up for periodic renewal. Property rights have been watered down as restrictions on the use of property are continually imposed to guard against abuse. It is important to note that just like any type of right, property rights have certain restrictions and is not without qualifications. 
The above discussion brings into view the interest of non-shareholding stakeholders. To some writers, the view of the corporation, which ascribes all the benefits and risks of the modern corporation squarely on shareholders, is not defensible. Nowadays profits are derived from harnessing intangible assets such as, labour and customer preferences, to generate wealth (Blair 1998:64). Boatright (1994) asks rhetorically, 'What's So Special about Shareholders?' and urges that shareholders do not need additional rights as they already have numerous rights including right to attend meetings, voting, and right of exit. He maintained that their interest in the firm is not long-term as otherwise thought (Boatright, 1994). This argument is inextricably linked with the fiduciary concept and is considered in the following paragraph in light of legislative provisions in Nigeria and the UK.

The Nigerian Companies and Allied Matters Act (CAMA) (2004) provides that,

"(1) a director of a company stands in a fiduciary relationship towards the company and shall observe the utmost good faith towards the company in any transaction with it or on its behalf. A director shall act at all times in what he believes to be the best interests of the company as a whole so as to preserve its assets, further its business, and promote the purposes for which it was formed, and in such manner as a faithful, diligent, careful and ordinarily skilful director would act in the circumstances.

The matters to which the director of a company is to have regard in the performance of his functions include the interest of the company's employees in general, as well as the interests of its members.

(5) Any duty imposed on a director under this section shall be enforceable against the director by the company. (CAMA 2004, Section 279 (1), (3), (4) and (9))"

The above provisions suggest that directors' duties under Nigerian law are quite extensive, as they must consider the interest of employees and its members. The above provision is however restricted when read in conjunction with section 79 (1) and (3) CAMA, which defines a 'member' of a company as anyone who subscribes to the memorandum and articles of association and holds at least one share. Also important is the fact that the above rights can only be enforced by the company through the board of directors acting as a collegiate body. This essentially means that the main actor is the shareholder.

In comparison, the provisions of the UK Companies Act with respect to the role of directors suggest that directors' duties under the UK Companies Act are quite wider than what obtains in Nigeria. In the UK, directors are enjoined to take into account the interest of employees, the impact of the company's operations on the community and environment, the need to foster the company's business relationships with suppliers, customers and others (UK Companies Act, 2006, section 172). However, it is only the members acting collectively that can enforce this breach of duty.

The purport of the statutory instruments considered makes the case that the impact of company operations is wide and far-reaching but legislators are circumspect in fettering directors' discretion with respect to the way that the company is run. It seems the freedom enjoyed by businesses to employ whatever strategy they desire in order to reach their ends is the cornerstone of economic development and legislators are cautious of restricting this freedom.

\section{CORPORATE MODEL/OWNERSHIP STRUCTURE AS IT AFFECTS CORPORATE POLICY}

Another perspective from which to view the objective of the firm, relates to diverse models of corporate governance practice underpinning different legal systems. Here, the paper evaluates the Anglo-American profitseeking firms who view stakeholder engagement as largely voluntary. Under this section the paper compares the Anglo-American model of the firm and the corporate model employed in most parts of continental Europe preaching social solidarity, i.e., Germany. Firms under the latter model view the firm as a social institution with a public interest at its heart. While the Anglo-American model is viewed as a private institution with the owners exercising little or no control over corporate executives. Although, one could argue that under the AngloAmerican model, stakeholders are represented on boards by the presence of non-executive directors; their mode of appointment makes us doubt their effectiveness in pursuing stakeholder interests.

Michel Albert identified two forms of Capitalism (Albert, 1993). The 'neo-American' model, practised in the UK and USA, and the 'Rhine' model, practised in parts of Western Europe and to a considerable extent in Japan. At the heart of the former model is a belief in the pursuit of individual self-interest with the market playing a prominent role. The latter model advances the interest and well being of a whole range of participants, providing an institutional framework to achieving that end. The important role of the state as an impartial umpire in not only creating a serene business environment but also interfering when the occasion demands was deemed as one of the core attributes of the 'Rhine' system. This arrangement promotes sustainable long-term relationships between the various groups making up the corporation (Roe, 1993). The firm, under this system, benefits from its relationship with other groups by recording lower transaction costs and improved information flow. The assumption is that this style of corporate ordering has advantages both in terms of fulfilling corporate 
objectives and wider social goals. With the predominating influence of Shareholder value in mind, this sought of relationship is harder to establish under the neo-American system with its emphasis on 'individualism' (Parkinson, 1993).

The paper considers the distinctive features of the ownership/management structure in two countries, with a social undertone to their management structure. These are Germany and Japan. In Germany there is in use the two-tier board structure, a high incidence of blockholding, and what we may call a representational system (Roe, 1993). The blockholders play an important role by monitoring managers and facilitating information flow from inside the firm. The two-tier board is divided into the supervisory board and executive board. Various interest groups i.e., employees, shareholders, banks, advisors, etc., within the organization are brought together and represented under the supervisory board setting. The role played by the above bodies ranges from giving technical advice, to accepting less than normal consideration in cases where the company is finding it difficult to post huge profits.

This marriage of ownership and control plays a great role in not only reducing information asymmetry and transaction costs but it also secures the stability of the firm. In Japan, ownership is quite concentrated with a small number of institutions controlling majority of shares (Taka, 1994). Wide and cross-ownership (a practice where a corporation allows trusted companies to hold its own shares, and in turn, the former would also hold shares in the latter) of shares pervade the business clime with organizations holding stakes, directly and indirectly, in each other, i.e., corporate affiliations (keiretsu), thereby making it difficult for company raiders to get in. Also the emphasis on the group contrasts sharply with the predominating view of individualism, which pervades Anglo-Saxon debate on the aim of the firm. In Japan, only as a last resort do employees get laid off (Taka, 1994, 61). The firms have a strong internal disciplining mechanism whereby managers and employees communicate effectively mainly on employee concerns and welfare.

Japanese and German systems are characterized as 'relationship-based system' compared with the 'marketbased system' of the US and UK (Suto and Hashimoto, 2006); with the former operating a system of strong employee participation. Importantly, it is suggested that these corporate systems have been influenced historically through political ideology (Bebcuck and Roe, 1999). The corporation in the above setting creates a close relationship with the employee, with the belief that poor relations can result in reduced productivity and loyalty, which adversely affects performance. Where a close-knit relationship is established between employee and management, consumer trends can easily be anticipated and product information understood in a fast and efficient manner.

The above goes to show that stakeholder rights have prominence in some jurisdictions than others. Some scholars explain it on the ground of legal origins (La Porta et al., 1997; Bebcuck and Roe, 1999; Roe, 2006) of these countries, while others highlight issues like political ideology, culture, values etc (Hill and Jones, 1992 , 134; Svendsen, 1998, 72; Licht et al., 2004). It is important to state here that, shareholder value, with its emphasis on market based finance, is still the driving force of Anglo-Saxon corporate governance and we are beginning to see a sought of convergence amongst systems.

Having in mind the purpose of this paper, the above goes to show that a country's finance model/ownership structure go a long way in influencing corporate policy. But it must be borne in mind that there are no neat classifications and in most cases integration of systems and mechanisms are required. The raft of bailouts enjoyed by financial services institutions in Nigeria $(2006-2009)$ and the UK $(2007-2009)$ demonstrates that in appropriate cases the State will intervene.

\section{THE ROLE OF MANAGEMENT IN STRIKING EQUIPOISE}

The assumption that shareholder interests can only be satisfied by taking account of stakeholder needs, and that long-term value maximization might be possible where companies undertake accountability to all their stakeholders has gained popularity amongst corporate executives in recent years. According to Miles, Hammond and Friedman (2002) some organisations have craved out new portfolios for management staff with positions for, community manager, social responsibility manager, and stakeholder manager. Generally, better managers are able to formulate sustainable business plans within the right corporate governance framework and therefore maximize value creation over the long term. Managers ought to be able to instigate business strategy that accommodates the needs of their stakeholders and that will at the same time guarantee higher financial returns for the business entity.

Managers make choices that affect all of us, whether directly or indirectly. These choices could either enhance or degrade the quality of our lives. The modern Corporation is so huge that its impact can be felt in all aspects of everyday life, with management required on a day-to-day basis to make decisions that will accommodate social welfare issues. To this end, a firm's social performance depends upon the weight given by human actors to social welfare. Accordingly good corporate governance as well as good corporate social responsibility is inextricably linked to good financial performance and management quality (Solomon, 2007, 15).

The modern business landscape is culturally complex, ethnically diverse and driven by profit. It 
increasingly reflects the community in which it operates. Relying on the studies on legal origins and political influences it will be difficult for managers to extricate themselves from the system under which they were trained. This system, ingrained in their subconscious, continually influences their behaviour and policies throughout their corporate career. The nature of the contract between business and community is continually renegotiated to reflect any changes in policy and corporate direction. With managers at the central node, it is their responsibility to reconcile divergent interests by making strategic decisions and allocating scarce resources in a fair and efficient manner consistent with the claims of all interested parties.

This leads to a consideration whether management has extra-legal obligations towards stakeholder groups? and if yes, what are they? and how are they supposed to know what it is?

Granted, managers have a special obligation to provide financial returns to shareholders but this has to be done within a permissible framework, having in mind the impact that pursuing this course of action may have for other individuals, the nature of public goods, the environment and the global revival against its continued indiscriminate degradation.

The long-term effect of mismanaging relationships with stakeholders is better imagined than experienced. For instance, the events precipitating the expulsion of Shell Petroleum Development Company Nigeria from Ogoni land (a local community and one of the main on-shore oil producing areas located within Nigeria's oil rich Niger Delta area) is instructive in this regard. After the execution of non-violent environmental campaigners known as the 'Ogoni Nine' on the $10^{\text {th }}$ of November, 1995 by the Nigerian government Shell faced unprecedented sabotage of its oil facilities by the locals. Shell was accused of complicity and painted as a corporate villain that would pursue profits at any cost social cost (Holzer, 2007, 295). Things got so bad, the local community single-handedly expelled Shell from its oil fields located within Ogoni land. Shell maintains that the Nigerian government carried out the trial and execution of the nine men, but the affected host community maintains that Shell was complicit in the whole affair. The effect of this episode is still visible to the present day as the widows of four of the Ogoni nine have instituted a case alleging infringement of the fundamental rights of the executed men and complicity between Shell and the Nigerian Government for the 1995 killing of their husbands. The matter was initially instituted in the US but when the US Court declined jurisdiction in 2013 (Kiobel v. Royal Dutch Petroleum Co., 2013) another matter was instituted in a Dutch Court in June 2017 (Kiobel v Royal Dutch Shell, 2019). A decision is expected in May 2019.

The expulsion of oil majors from the oil fields in Ogoni Land indicates the importance of managing stakeholder relationships. The loss of reputation and profits subsequently suffered by Shell as a result of the Ogoni situation cannot be quantified. Shell had to shut down some of its facilities in 2006, reducing production by $50 \%$ (Shell Petroleum Development Company, 2006). From then on, the situation has continued to deteriorate, with reports of kidnappings of oil workers and flow station sabotage. This episode was responsible for the deterioration of the relationship between Shell and various communities in the Delta and the company has been working hard to improve its perception. With most local communities becoming hostile to the presence of the multinationals with a requirement for government forces to protect oil workers and installations. This goes to show the disastrous consequences an enterprise might suffer if a stakeholder group withdraws its support from the firm. It is recommended that a dispute or crisis should be tackled by a strategy of discussion through accommodation. Companies are advised not to be too high-handed in their approach but should address the issue by engagement with aggrieved parties.

Continuing from the above example, we ask ourselves; do companies operating in areas with high kidnap rates have to consider the interest of the kidnappers? Are they to be considered as stakeholders? Arguably, we could say the kidnappers have forced themselves into contention to the extent that they are basing their actions on the fact that they and their immediate environment have been neglected. And considering the manner of influence that armed groups wield in the Niger Delta region, they can, and have consistently continued to cause significant damage to the companies operating in the area. The above is important having in mind Freeman's comment that;

"Some groups may have as an objective simply to interfere with the smooth operations of our business. For instance, some corporations must count "terrorist groups" as stakeholders. As unsavoury as it is to admit that such illegitimate groups have a stake in our business, from the standpoint of strategic management, it must be done" (Freeman, 1984:53).

Following from the above, the issue of stakeholder salience has to be considered. How do managers prioritise between different stakeholder groups? Which group has a predominating interest that needs to be settled before that of others? The stakeholder group that receives priority from management will be those whom managers perceive as salient (Agle et al., 510). Clarkson (1995) suggests that the corporation's survival and continued success depends on the ability of managers to balance and create sufficient wealth, value, or satisfaction for those who belong to various stakeholder groups, to enable each group continue as a part of the corporation's stakeholder system. Clarkson (1995:112), goes ahead to argue that managers, can subordinate the claims of stakeholders where they maintain that the interest of shareholders is supreme. But immediately they 
start resolving conflicts of interest between stakeholder groups they can no longer rely on "the invisible hand" to solve problems. In this context, the invisible hand promotes the idea that the market will direct capital to the area where it is most needed without paying attention to other issues (Smith, 1776).

We have seen from the Shell example above, how failure to constructively engage important stakeholders can result in increased cost, loss of revenue and damage to reputation. The view that managers are only responsible to shareholders seems to be waning, and there is an emergence of a new paradigm requiring managers to take into account and fulfil a wider responsibility to various stakeholder groups. This means that managers should employ a systematic approach to resolving apparent conflicts and the fair distribution of wealth and value created by the corporation through the inputs of the stakeholder groups. An appropriate level of fairness and balance must be struck, so that each stakeholder believes that it is getting a fair deal. Where this is not done, the affected group might be forced to withdraw its support with the impending disastrous consequences for the corporation.

The role of management in this respect cannot be overstated. They are the principal architects of corporate conscience and as such must manage the challenges of pursuing profit while keeping an eye on social welfare issues. The difficulty of balancing varied interest becomes pronounced when we consider the role played by individuals in the corporate setting. As shareholders, we demand unrestricted maximization of our investment, while as citizens we are quick to demand that firms behave responsibly taking into account numerous interests. This demand to juggle and balance numerous interests does not make decision making easy for corporate managers who have to balance these interests on a continual basis.

\section{CONCLUSION}

Whatever the arguments, the current trend towards controlling the effects of climate change has made economic theories in support of shareholder wealth maximization come under increasing attack in recent years. To add a more explicit social dimension to corporate thinking, the economic objective of the firm could be altered to reflect a social oriented perspective. We might do nothing and trust the 'allocative efficiency' of our markets to reward or punish management who chose to or neglect to consider the social impacts of their firms in the hope that markets will punish such firms. The paper does not attempt to defend any specific way of realising the objectives of the firm. It has merely sought to consider the various approaches adopted by managers depending on their personal conviction and influenced to a considerable degree by the corporate model of their various jurisdictions.

In sum, the objective of corporate governance in this respect, cannot, strictly speaking, be exclusively classified into two broad categories, i.e., social welfare or profitability. Profit maximization, which is at the heart of any business enterprise, should be pursued in an all-inclusive manner, wherein a range of other interests and inputs is duly considered.

From the above, the title of this research paper may well have read, 'Balancing the Objectives of Corporate Governance: Social Welfare and Profitability'. The point needs to be reiterated, although it seems obvious to the initiated and less so to the un-informed, that the paper is not urging that one paradigm is economically or politically correct than the other as it would be catastrophic to lean totally to one of these systems. Rather, the paper attempts to throw up a few issues implicit in both systems, which aim to establish that the concept of 'profits' and 'social welfare' may not be strange bedfellows after all.

\section{BIBLIOGRAPHY}

Agle, B., Mitchell, K., Sonnenfeld, J., 1999. Agle B. R., Mitchell, K. R. Sonnenfeld, J. A. (1999), What Matters to CEOs? An Investigation of Stakeholder Attributes and Salience, Corporate Performance and CEO Values, , The Academy of Management Journal, Vol.42, No. 5. Acad. Manage. Rev. 42, 507 - 525.

Albert, M., 1993. Capitalism against Capitalism. Whurr Publishers, London, UK.

Ansoff, H., 1965. Corporate Strategy. Mcgraw Hill, New York.

Bebcuck, L., Roe, M., 1999. A Theory of Path Dependence in corporate Governance and Ownership. Stanford Law Rev. 52, 127.

Berle, A., Means, G., 1932. The Modern Corporation and Private Property. New York.

Black's Law Dictionary, 8th ed, 2004.

Blair, M., 1998. Who's Interest Should Corporations Serve?, in: Clarkson, M. (Ed.), The Corporation and Its Stakeholders: Classic and Contemporary Reading. Toronto University Press, Toronto.

Boatright, J., 1994. Fiduciary Duties and the Shareholder-Management Relation or What's So Special About Shareholders? Bus. Ethics Q. 4, 393 - 407.

Boatright, R., 1999. Ethics in Finance. Blackwell Publishing, Oxford.

Bratton, W., 2001. Enron and Dark Side of Shareholder Value. Tulane Law Rev. 76, 1283.

Cartwright, D., 1990. What Price Ethics. Manag. Audit. J. 5, 28 - 31.

Clarkson, M., 1995. A Stakeholder Framework for Analysing and Evaluating Corporate Social Performance. 
Acad. Manage. Rev. 20, 92 - 117.

Cochran, P., Wood, R., 1984. Corporate Social Responsibility and Financial Performance. Acad. Manage. J. 27, $42-56$.

Demsetz, H., Lehn, K., 1985. The Structure of Corporate Ownership: Causes and Consequences. J. Polit. Econ. 93, $1155-1177$.

Dodd, E., 1932. For Whom Are Corporate Managers Trustees? Harv. Law Rev. 45, 1145 - 1163.

Donaldson, T. and Preston, L. E. (1995). The Stakeholder Theory of the Corporation: Concepts, Evidence and Implications, Academy of Management Review, 20/1: pg 65-92.

Fama, E.F., 1970. Efficient Capital Markets: A Review of Theory and Empirical Work. J. Finance 25, 383 - 417.

Freeman, R.E., 1984. Strategic Management: A Stakeholder Approach. Pitman, Boston, MA.

Freidman, A.L., Miles, S., 2006. Stakeholders: Theory and Practice. Oxford University Press.

Friedman, M., 1962. Capitalism and Freedom. Chicago University Press, Chicago.

Goodpaster, K., 1991. Business Ethics and Stakeholder Analysis. Bus. Ethics Q. 1, 53 - 73.

Hasnas, J., 1998. The Normative Theories of Business Ethics. A Guide for the Perplexed. Bus. Ethics Q. 8, 19 42.

Hill, C., Jones, T., 1992. Stakeholder-Agency Theory. J. Manag. Stud. 29, $131-154$.

Holzer, B., 2007. Framing the Corporation: Royal Dutch/Shell and Human Rights Woes in Nigeria. J. Consum. Policy 30, $281-301$.

Jensen, M., Meckling W., 1976. Theory of the Firm: Managerial Behaviour, Agency Costs and Ownership Structure. J. Financ. Econ. 3, $305-360$.

Kujala J and I Ansoff (1965) Corporate Strategy, McGraw-Hill

Kaplow, L., Shavel, S., 2001. Fairness versus Welfare. Harv. Law Rev. 114, 916 - 1338.

Kiobel v. Royal Dutch Petroleum Co., 2013.

Kiobel v Royal Dutch Shell, 2019.

La Porta, R., Lopez, S., Silanes, F., Vishny, R., 1997. Legal Determinants of External Finance. NBER Working paper.

Leavitt, T., 1958. The Dangers of Social Responsibility. Harv. Bus. Rev. 36, $41-50$.

Licht, A., Goldschmidt, C., Schwartz, S., 2004. Culture, Law, and Corporate Governance.

Marcoux, A.M., 2003. A Fiduciary Argument Against Stakeholder Theory. Bus. Ethics Q. 13, 1 - 24.

Miles S., Hammond K. and Friedman A. L. (2002), ACCA Research Report No.77: Social and Environmental Reporting and Ethical Investment: London:

Monks, R.A.G., Minow, N., 2004. Corporate Governance, 3rd ed. Blackwell Publishing.

Moskowitz, M., 1972. Choosing Socially Responsible Stocks. Bus. Soc. Rev. 1, 71 - 75.

Ogus, A., 1994. Regulation: Legal Form and Economic Theory. Clarendon Press, Oxford.

Parkinson, J., 1993. Corporate Power and Responsibility: Issues in the Theory of Company Law. Clarendon Press, Oxford.

Quinn, D., Jones, T., 1995. An Agent Morality View of Business Policy. Acad. Manage. Rev. 20, 22 - 42.

Rawls, J., 1971. A Theory of Justice. Harvard University Press, Cambridge Massachusetts.

Roe, M., 2006. Legal Origins and Modern Stock Markets. Harv. Law Rev. 120, 460 - 527.

Roe, M., 2002. Political Preconditions to Separating Ownership from Control. Stanford Law Rev. 53, 539 - 606.

Roe, M., 1993. Some Differences in Corporate Structure in Germany, Japan and the United States. Yale Law J. $102,1927-2003$

Shell Petroleum Development Company, 2017. Sustainability Report 2017.

Shell Petroleum Development Company, 2006. Shell Sustainability Report 2006.

Shleifer, A., Vishny, R., 1986. Large Shareholders and Corporate Control. J. Polit. Econ. 94, 461 - 488.

Smith, A., 1776. An Inquiry into the Causes and the Wealth of Nations. Oxford University Press, Oxford.

Solomon, J., 2007. Corporate Governance and Accountability, 2nd ed. John Wiley.

Sternberg, E., 2000. Just Business: Business Ethics in Action, 2nd ed. Oxford University Press, Oxford.

Suto, M., Hashimoto, M., 2006. Will Japanese Corporate Governance System Survive? Challenges of Toyota and Sony, in: Mallin, C. (Ed.), International Corporate Governance: A Case Study Approach. Edward Elgar Publishing, UK, pp. 246-266.

Svendsen, A., 1998. The Stakeholder Strategy: Profiting from Collaborative Business Relations. Berrett-Koehler Publishers, San Francisco, CA.

Taka, I., 1994. Business Ethics: A Japanese View. Bus. Ethics Q. 4, 53 - 78.

Task Force on Corporate Social Performance Business and Society, 1980. Strategies for the 1980s. US Department of Commerce, Washington D.C.

Tirole, J., 2001. Corporate Governance. Econometrica 69, 1 - 35. https://doi.org/https://doi.org/10.1111/14680262.00177

UK Companies Act, 2006. 
Vance, S., 1975. Are Socially Responsible Corporations Good Investment Risks. Manag. Rev. 64, 18 - 24.

Waddock, S., Graves, S., 1997. The Corporate Social Performance-Financial Performance Link. Strateg. Manag. J. $18,303-319$.

Williamson, O.E., 1985. The Economic Institutions of Capitalism. Free Press, New York.

Wood, D., 1991. Corporate Social Performance Revisited. Acad. Manage. Rev. 16, 691 - 718. 